\title{
The emergence and transformation of medieval Cumbria
}

The Cumbrian kingdom is one of the more shadowy polities of early medieval northern Britain. ${ }^{1}$ Our understanding of the kingdom's history is hampered by the patchiness of the source material, and the few texts that shed light on the region have proved difficult to interpret. A particular point of debate is the interpretation of the terms 'Strathclyde' and 'Cumbria', a matter that has periodically drawn comment since the 1960s. Some scholars propose that the terms were applied interchangeably to the same polity, which stretched from Clydesdale to the Lake District. Others argue that the terms applied to different territories: Strathclyde was focused on the Clyde Valley whereas Cumbria/Cumberland was located to the south of the Solway. The debate has significant implications for our understanding of the extent of the kingdom(s) of Strathclyde/Cumbria, which in turn affects our understanding of politics across tenth- and eleventh-century northern Britain. It is therefore worth revisiting the matter in this article, and I shall put forward an interpretation that escapes from the dichotomy that has influenced earlier scholarship. I shall argue that the polities known as 'Strathclyde' and 'Cumbria' were connected but not entirely synonymous: one evolved into the other. In my view, this terminological development was prompted by the expansion of the kingdom of Strathclyde beyond Clydesdale.

This reassessment is timely because scholars have recently been considering the evolution of Cumbrian identity across a much longer time-period. In 1974 the counties of Cumberland and Westmorland were joined to Lancashire-North-of the-Sands and part of the West Riding of Yorkshire to create the larger county of Cumbria. In the ensuing decades a sense of modern

\footnotetext{
${ }^{1}$ This article is based on a paper presented at the XIV International Congress of Celtic Studies, NUI Maynooth, 2011. I am grateful to Professor Dauvit Broun, Professor Thomas Charles-Edwards, Dr Jonathan Grove and Professor Angus Winchester for their remarks on a draft. I would also like to thank Professor Thomas Clancy and Dr Davyth Hicks for allowing me to cite their unpublished work.
} 
Cumbrian identity has started to emerge, prompting new investigations of the area's history from early medieval times to the present day. This trend is encapsulated by the Victoria County History of Cumbria project and also by a conference on Cumbrian identity that was held in $2009 .^{2}$ The area has long been perceived to have geographical unity, and the landscape engendered a distinctive pattern of land tenure and rural society that stretched across the territory of modern Cumbria. ${ }^{3}$ Even so, local identities have always been strongly rooted and certain factors have limited the emergence of a regional identity within the bounds of modern Cumbria. ${ }^{4}$

There is a complicating factor for discussions of the history of Cumbria in the medieval period, namely, the application of Cumbrian terminology to the area north of the Solway. Scholars who work on both Scottish and northern English medieval history have long been aware of this phenomenon, leading them to refer to 'Scottish Cumbria' and 'English Cumbria', or to 'northern Cumbria' and 'southern Cumbria'. ${ }^{5}$ It is often assumed that this terminology is a relic of a once-great kingdom that straddled the modern Anglo-Scottish border, but not all scholars would concur with this view. I shall therefore begin by reviewing

\footnotetext{
2 'The Victoria County History for Cumbria', http://www.cumbrialocalhistory.org.uk/vch.html, consulted on 19/12/12; Transactions of the Cumberland and Westmorland Antiquarian and Archaeological Society [TCWAAS], $3^{\text {rd }}$ ser. 11 (2011), 11-111.

${ }^{3}$ Matthew Townend, 'Cumbrian Identities: Introduction', TCWAAS, $3^{\text {rd }}$ ser. 11 (2011), 11-14. For land tenure, see Angus J. L. Winchester, 'Regional Identity in the Lake Counties: Land Tenure and the Cumbrian Landscape', Northern History 42 (2005), 29-48.

${ }^{4}$ For local identities, see Angus J. L. Winchester, 'Personal Names and Local Identities in Early Modern Cumbria', TCWAAS, $3^{\text {rd }}$ ser. 11 (2011), 29-49; Mike Huggins, "'Sport helps make us what we are": the Shaping of Regional and Local Sporting Identities in Cumbria c.1800-1960', ibid., 81-96. For the limitations, see John K. Walton, 'Cumbrian Identities: Some Historical Contexts', ibid., 15-27.

${ }^{5}$ E.g. G. W. S. Barrow, 'The Pattern of Lordship and Feudal Settlement in Cumbria', Journal of Medieval History 1 (1975), 117-33, at 125, 132; Barrow, The Kingdom of the Scots: Government, Church and Society from the Eleventh to the Fourteenth Century, $2^{\text {nd }}$ edn (Edinburgh, 2003), 137, 204, 207; W. M. Aird, 'Northern England or Southern Scotland? The Anglo-Scottish Border in the Eleventh and Twelfth Centuries and the Problem of Perspective', in John C. Appleby and Paul Dalton (eds), Government, Religion and Society in Northern England 1000-1700 (Stroud, 1997), 27-39; G. W. S. Barrow, 'King David I, Earl Henry and Cumbria', TCWAAS, $2^{\text {nd }}$ ser. 99 (1999), 117-27, at 119; Alexander Grant, 'Lordship and Society in TwelfthCentury Clydesdale', in Huw Pryce and John Watts (eds), Power and Identity in the Middle Ages: Essays in Memory of Rees Davies (Oxford, 2007), 98-124, at 109.
} 
previous interpretations of medieval Cumbria, before assessing instances of Cumbrian terminology in tenth-, eleventh- and twelfth-century texts.

\section{$\underline{\text { Previous interpretations of medieval Cumbria }}$}

W. F. Skene was the first historian to discuss the name of the Cumbrian kingdom in detail.

He observed that 'the terms Cumbria and Cumbri are not applied to any part of the territories and people of Britain by any writer prior to the eleventh century' ${ }^{6}$ In fact, as we shall see, there are references to a Cumbrian polity in Latin and Old English texts from the mid-tenth century onwards. Skene's main point, however, is worth noting: Cumbrian political terminology appears at a relatively late stage and its emergence requires explanation. Skene asserted that terra Cumbrorum or Cumbra land was a kingdom that stretched from the Clyde to the Derwent, and this view prevailed for nearly a century. ${ }^{7}$

In 1962 D. P. Kirby provided a new interpretation, arguing that Cumbria and Strathclyde were separate polities: Cumbria/Cumberland lay to the south of the Solway, whereas Strathclyde was focused on Dumbarton and the Clyde. ${ }^{8}$ Cumbria was incorporated into Strathclyde at the start of the tenth century, but thereafter the two territories were sometimes ruled by separate kings. ${ }^{9}$ Both polities were influenced to a considerable degree by the kings of Scots, and Cumbria was sometimes entrusted to the heirs of the Scottish kings. ${ }^{10}$ Kirby's article remains an insightful discussion of the political history of the northern Brittonic kingdom, but there are two significant obstacles to his argument that Cumbria and

\footnotetext{
${ }^{6}$ W. F. Skene, 'Notes on Cumbria', apud Alexander Penrose Forbes (ed.), Lives of S. Ninian and S. Kentigern, Historians of Scotland 5 (Edinburgh, 1874), 330-5, at 330-1.

${ }^{7}$ Ibid., 333.

${ }^{8}$ D. P. Kirby, 'Strathclyde and Cumbria: a Survey of Historical Development to 1092 ', TCWAAS, $2^{\text {nd }}$ ser. 62 (1962), 77-94, at77, 82, 86 n. 47. He changed his view in his article, 'Britons and Angles', in Who were the Scots?, ed. Gordon Menzies (London, 1971), 87, but did not explain the reasons.

${ }^{9}$ Kirby, 'Strathclyde and Cumbria', 86-90.

${ }^{10}$ Ibid., 87, 89, 92; Kirby, 'Britons and Angles', 87-8.
} 
Strathclyde were separate entities. First, medieval writers applied Cumbrian terminology to areas north of the Solway Firth, which surely calls into question the idea that Cumbria lay solely to the south of the Solway. Second, Kirby's account relies on the fourth book of John of Fordun's Chronica Gentis Scotorum, which was written in the 1380s. For example, Kirby accepted that the Scottish king Constantín mac Áeda set Cumbria aside to be ruled by heirs to the Scottish kingship. ${ }^{11}$ Yet Dauvit Broun has recently criticised the view that that Cumbria was an appanage, and he has raised significant questions about Fordun's presentation of tenth-century history. Broun has identified Richard Vairement as the author of an account underlying Fordun's main source, and he has shown that Vairement's portrayal of Cumbria was influenced by the position of Gascony in $1259 .{ }^{12}$ Given this mid-thirteenth-century gloss, it seems unwise to place any reliance on the account of Strathclyde and Cumbria that Fordun transmitted. $^{13}$

In 1966 P. A. Wilson exposed some of the flaws in Kirby's argument and proposed instead that 'Strathclyde' and 'Cumbria' were alternative names for the same kingdom. ${ }^{14}$ A key piece of evidence in favour of this argument is Æthelweard's late-tenth-century Latin translation of a version of the Anglo-Saxon Chronicle. Ethelweard selected the term Cumbri to translate Strecledwalas ('Strathclyde Britons'), which appears in the common stock of the Chronicle

\footnotetext{
${ }^{11}$ W. F. Skene (ed.), Johannis de Fordun Chronica Gentis Scotorum, Historians of Scotland, 2 vols (Edinburgh, 1871-2), i, 163-4; ii, 155. This is also accepted by Alfred P. Smyth, Warlords and Holy Men: Scotland AD 801000 (London, 1984), 218-29.

${ }^{12}$ Dauvit Broun, Scottish Independence and the Idea of Britain: from the Picts to Alexander III (Edinburgh, 2007), 215-68; cf. Dauvit Broun, 'The Welsh Identity of the Kingdom of Strathclyde c.900-c.1200', Innes Review 55 (2004), 111-80, at 131 n.84.

${ }^{13}$ Other historians have questioned Fordun's testimony, e.g. Benjamin Hudson, 'Elech and the Scots in Strathclyde', Scottish Gaelic Studies 15 (1988), 145-9; Alan Macquarrie, 'The Kings of Strathclyde, c.4001018', in Alexander Grant and Keith J. Stringer (eds.), Medieval Scotland: Crown, Lordship and Community: Essays presented to G. W. S. Barrow (Edinburgh, 1993), 1-19, at 15; Tim Clarkson, The Men of the North: the Britons of Southern Scotland (Edinburgh, 2010), 161.

${ }^{14}$ P. A. Wilson, 'On the Use of the Terms "Strathclyde" and "Cumbria", TCWAAS, $2^{\text {nd }}$ ser. 66 (1966), 57-92.
} 
for $875 .{ }^{15}$ I am not, however, persuaded by Wilson's suggestion that Cumbri was a Latinised version of a term in Æthelweard's source; this seems improbable since all of the extant versions of the Chronicle contain the term Strecledwalas rather than Cumbras in the 875 entry. ${ }^{16}$ It is more likely that Æthelweard decided to replace the Chronicle's Strecledwalas with a term appropriate to the late-tenth-century context in which he was writing, namely, Cumbri. Thus, one problem with Wilson's article is the failure to address the time-lag between the use of the name 'Strathclyde' and the emergence of Cumbrian terminology. ${ }^{17}$ This matter remains to be explained, although Wilson's evidence strongly suggests that the polities known as 'Strathclyde' and 'Cumbria' were closely related.

P. A. Wilson's argument has proved influential, but Charles Phythian-Adams put forward a different account of the relationship between the terms 'Strathclyde', 'Cumbria' and 'Cumberland' in his 1996 book Land of the Cumbrians. ${ }^{18}$ He argued that Strathclyde and the area south of the Solway were generally ruled separately, although the two polities might be combined into one overlordship: 'the King of the Cumbrians, therefore, would appear to have been nothing less than over-king for all of these territories (north and south of the Solway)'. ${ }^{19}$ Thus Phythian-Adams, unlike D. P. Kirby, took into account the application of Cumbrian terminology to the area north of the Solway. ${ }^{20}$ However, the notion that Strathclyde and Cumbria were separate kingdoms shares Kirby's problematic reliance on John of Fordun's

\footnotetext{
${ }^{15}$ A. Campbell (ed. and tr.), Chronicon Athelweardi The Chronicle of Athelweard (London, 1962), 41. For the 875 entry in the Chronicle, see below n. 28.

${ }^{16}$ Wilson, 'On the Use', pp. 69, 76-7; Phythian-Adams, Land of the Cumbrians, 193 n.5.

17 This point has been remarked upon both before and after Wilson's article was published; see, for example, Skene, 'Notes on Cumbria', 332; Phythian-Adams, Land of the Cumbrians, 112; Davyth A. Hicks, 'Language, History and Onomastics in Medieval Cumbria: an Analysis of the Generative Usage of the Cumbric Habitative Generics Cair and Tref', unpublished Ph.D. thesis (Edinburgh University, 2003), 16, 30-1; Thomas Owen Clancy, 'Ystrad Clud', in John T. Koch (ed.), Celtic Culture: A Historical Encyclopedia, 5 vols (Santa Barbara CA and Oxford, 2006), v, 1818-21, at 1819.

${ }^{18}$ Charles Phythian-Adams, Land of the Cumbrians: a Study in British Provincial Origins, A.D. 400-1200 (Aldershot, 1996), 109-14.

${ }^{19}$ Ibid., 114.

${ }^{20}$ Ibid., 110.
} 
chronicle. ${ }^{21}$ Phythian-Adams interprets Cumberland as a royal core of land to the south of the Solway, and this offers a useful insight into the functioning of kingship in the area. I will argue, however, that tenth-century instances of the Old English term Cumbra land applied to a large kingdom that straddled the Solway. ${ }^{22}$ Thus, Phythian-Adams offers a different interpretation for each of the terms Strathclyde, Cumbria and Cumberland, but it is questionable whether tenth-century texts bear out this range of meanings. Nevertheless, his book contains stimulating discussion of the relationship between ethnic and political identity amongst the Cumbrians. He has taken this approach further in a recent article on early medieval Cumbrian identities, in which he detects a shift from an ethnically defined people to a regional society with distinctive customs. ${ }^{23}$

The relationship between ethnic and political identity also features in Alan James's recent analysis of the 'Cumbric diaspora'. ${ }^{24}$ James identifies the Cumbrians with Brittonic-speakers whose lives were disrupted by political instability in late-ninth- and early tenth-century northern Britain. This volatility prompted migration towards the Solway basin and other parts of the North and Midlands of England, as well as parts of southern Scotland. The migrants gave their name to a polity in the Solway basin, which eventually came under the remit of the Strathclyde dynasty. However, the prime movers in the 'Cumbric diaspora' were people fleeing political turmoil and seeking new economic opportunities. Thus James's article questions the extent to which the emergence of Cumbrian terminology was prompted by political developments.

\footnotetext{
${ }^{21}$ Ibid., 112-16, criticised in Broun, 'Welsh Identity', 130.

${ }^{22}$ See below, pp. 00-00.

23 'From Peoples to Regional Societies. The Problem of Early Medieval Cumbrian Identities', TCWAAS, $3^{\text {rd }}$ ser. 11 (2011), 51-64.

24 'A Cumbric Diaspora?', in Oliver J. Padel and David N. Parsons (eds.), A Commodity of Good Names: Essays in Honour of Margaret Gelling (Donington, 2008), 188-203; cf. James, 'Dating Brittonic Place-Names in Southern Scotland and Cumbria', Journal of Scottish Name Studies 5 (2011), 91-2.
} 
In short, two main points of debate emerge from the secondary literature concerning medieval Cumbria. First, there is the question of whether Strathclyde and Cumbria were synonymous or separate entities. In this article I attempt to avoid the dichotomy by arguing that Strathclyde evolved into Cumbria: the expansion of the kingdom of Strathclyde beyond the limits of the Clyde Valley necessitated the use of new nomenclature. The second point of debate is the 'ethnic' connotations of Cumbrian terminology; was it applied solely to Brittonic-speakers? The medieval writers discussed in this article tended to use the terms in relation to a specific king, kingdom or (latterly) region. Thus I would argue that the emergence of terms such as Cumbra land or terra Cumbrorum was prompted by a political development, namely the expansion of the kingdom of Strathclyde. However, these terms translate literally as 'land of the Cumbrians', indicating that the polity was associated with a specific people or ruling dynasty.

\section{The Cumbrian kingdom in the tenth century}

In this section I aim to establish three points: that the term 'Strathclyde' was generally replaced by Cumbrian terminology; that the latter applied to areas north and south of the Solway; and that Cumbrian terminology had a political resonance. The kingdom name 'Strathclyde' was itself a relative recent coinage; the Clyde kings had previously been designated rulers of their chief citadel, Al Clut (Dumbarton Rock). ${ }^{25}$ The fort was attacked in 870 by the Scandinavian leaders Óláfr and Ívarr, who besieged it for four months. They eventually overcame it and captured large numbers of slaves, whom they transported to

\footnotetext{
${ }^{25}$ AU 694.6 (ed. Mac Airt and Mac Niocaill, 154-5); AT [693] (ed. Stokes, 213); The Chronicle of Ireland, tr. Thomas Charles-Edwards, 2 vols (Liverpool, 2006), i, 171. The presence of this entry in both AU and AT indicates that it was part of the contemporary 'Chronicle of Ireland'. This concept has recently been criticised by Daniel Mc Carthy, The Irish Annals: their Genesis, Evolution and History (Dublin, 2008), pp. 111, 168-97, but defended by Nicholas Evans, The Present and the Past in Medieval Irish Chronicles, Studies in Celtic History 27 (Woodbridge, 2010). Cf. A. O. Anderson and M. O. Anderson (ed. and tr.), Adomnán's Life of Columba (Oxford, 1991), i. 15 (pp. 38-9).
} 
Dublin. ${ }^{26}$ Shortly afterwards Arthgal rex Britanorum Sratha Cluade ('king of the Britons of Strathclyde') was killed according to the reconstructed 'Chronicle of Ireland'. This chronicle was probably kept in the central east of Ireland, and so the kingdom's new name must have spread quickly across the Insular world. ${ }^{27}$ The name also appears in the common stock of the Anglo-Saxon Chronicle for 875, which records that the Scandinavian leader Hálfdan established winter quarters on the Tyne and oft hergade on Peohtas 7 on Strecledwalas. ${ }^{28}$ The common stock was compiled under the aegis of King Alfred (d. 899), and the chronicler paid particular attention to the movements of Scandinavian leaders during the period $865-92 .{ }^{29}$ The change in nomenclature seems to have been prompted by the siege of Dumbarton Rock rather than the rise of a new ruling dynasty. Arthgal belonged to the same dynasty as former rulers of Al Clut according to the pedigree of his son, which features in a tenth-century Welsh genealogical compilation. ${ }^{30}$ The slighting of the great fortress on the north side of the Clyde may have encouraged the kings to focus their attentions on the Clyde Valley, hence their identification with a polity known as $(Y)$ strat Clut ('the valley of the Clyde'). ${ }^{31}$ Thereafter

\footnotetext{
${ }^{26}$ AU 870.6, 871.2 (ed. Mac Airt and Mac Niocaill, 326-7); CS [871] (ed. Hennessy, pp. 162-3); Chronicle of Ireland, ed. Charles-Edwards, p. 322; AC 871 (A \& B) (ed. Dumville, 12-13); Brenhinoedd y Saeson, 'The Kings of the English', A.D. 682-954: Texts P, R, S in Parallel (Aberdeen, 2005), 870 P, R \& S (pp. 26-7). For the textual history of the Welsh chronicles, see below p. 00.

${ }^{27}$ AU 872.5 (ed. Mac Airt and Mac Niocaill, 328-9); CS [872] (ed. Hennessy, 162-3); Chronicle of Ireland, ed. Charles-Edwards, i, 9-15, 324; Evans, The Present, p. 24.

28 'often ravaged among the Picts and the Strathclyde Britons'. Janet Bately (ed.), The Anglo-Saxon Chronicle: a Collaborative Edition. Vol. 3, MS A (Cambridge, 1986), 49 [ASC A]; Simon Taylor (ed.), The Anglo-Saxon Chronicle ... Vol. 4, MS B (Cambridge, 1983), 36; Katherine O'Brien O'Keeffe (ed.), The Anglo-Saxon Chronicle ... Vol. 5, MS C (Woodbridge, 2001), 60-1; G. P. Cubbin (ed.), The Anglo-Saxon Chronicle ... Vol. 6 , MS D (Woodbridge, 1996), p. 26; Susan Irvine (ed.), The Anglo-Saxon Chronicle ... Vol. 7, MS E (Cambridge, 2004), 50. See also W. H. Stevenson, Asser's Life of King Alfred, ed. (Oxford, 1904), 35-6, which drew on a version of the Chronicle.

${ }^{29}$ David N. Dumville, 'Vikings in Insular Chronicling', in Stefan Brink and Neil Price (eds.), The Viking World, (New York, 2008), 350-67, at 354; Clare Downham, 'Annals, Armies and Artistry: "The Anglo-Saxon Chronicle”, 865-96', Anglo-Saxon 10 (2010), 9-37; Alex Woolf, 'Reporting Scotland in the Anglo-Saxon Chronicle', in A. Jorgensen (ed.), Reading the Anglo-Saxon Chronicle: Language, Literature, History (Turnhout, 2010), 221-39, at 225; Simon Keynes, 'Manuscripts of the Anglo-Saxon Chronicle', in Richard Gameson (ed.), The Cambridge History of the Book in Britain (Cambridge, 2011), 537-52, at 539-40.

${ }^{30}$ P. C. Bartrum (ed.), Early Welsh Genealogical Tracts (Cardiff, 1966), 10; David E. Thornton, Kings, Chronicles and Genealogies: Studies in the Political History of Early Medieval Ireland and Wales (Oxford, 2003), 15, 23, 95; Clarkson, Men of the North, 31, 42, 162.

${ }^{31}$ Macquarrie, 'Kings of Strathclyde', 19; Broun, 'Welsh Identity', 111-12; Clancy, 'Ystrad Clud', 1819. The modern Welsh term for Strathclyde is Ystrad Glud (see, for example, A. O. H. Jarman, Y Gododdin: Britain's Oldest Heroic Poem (Llandysul, 1988), map (p. viii)). In medieval Welsh orthography, $t$ often represented $d$,
} 
Govan (in the Clyde Valley) emerged as a major political and ecclesiastical centre, whereas the Lennox seems to have become less pivotal to the kingdom. ${ }^{32}$

If geo-political change prompted the emergence of the term 'Strathclyde', the appearance of Cumbrian terminology may also be linked to a transformation of the kingdom's fortunes. The term 'Strathclyde' related to rulership of a river valley; similar polities were known elsewhere in the Brittonic-speaking world, such as Ystrad Tywi in southern Wales. ${ }^{33}$ In contrast, Cumbrian terminology derives from the word Cymry (*com-brogi) which originally meant 'the inhabitants of the same bro (locality)'. In Roman times, Latin-speakers were distinguished from speakers of the local Brittonic vernacular, namely, Cymraeg, and consequently all of the Britons came to be designated Cymry. ${ }^{34}$ Thus the author of the tenthcentury Welsh text Armes Prydein proclaimed Cornyw a Chludwys eu kynnwys genhyn ('the men of Cornwall and of the Clyde will be made welcome among us (Cymry)' $).{ }^{35}$ It is likely that the ruling dynasty of Dumbarton/Strathclyde considered themselves to be Cymry and that their subjects were identified as Cymry in turn. This self-identification may predate our period considerably since the term was borrowed into English as Cumbras no later than the

\footnotetext{
and the prosthetic vowel (the $Y$ - of $Y$ strat) may have developed by the late ninth century. See D. Simon Evans, $A$ Grammar of Middle Welsh (Dublin, 1964), 11-12.

${ }^{32}$ For contrasts between the Lennox and Clydesdale, see Simon Taylor, 'The Early History and Languages of West Dunbartonshire', in I. Brown (ed.), Changing Identities, Ancient Roots. The History of West Dunbartonshire from Earliest Times (Edinburgh, 2006), 12-66, at 26 (Gaelic influence in the Lennox); A. Ross, The Kings of Alba c. 1000-c. 1130 (Edinburgh, 2011), 141-3 (land assessments). For Govan, see S. T. Driscoll, Govan from Cradle to Grave (Govan lecture, 2004); B.E. Crawford, The Govan Hogbacks and the MultiCultural Society of Tenth-Century Scotland (Govan lecture, 2005), 18-23.

${ }^{33}$ See e.g. AC B [1047], C [1048] (ed. Williams ab Ithel, 24). Ystrad Tywi was sometimes, but not always, seen as part of the kingdom of Dyfed: Thomas Charles-Edwards, Wales and the Britons 350-1064 (Oxford, 2012), 18-20. Closer to Strathclyde, Nithsdale had an independent ruler during the first half of the twelfth century: Richard Oram, The Lordship of Galloway (Edinburgh, 2000), 26, 55-6, 89, 197.

${ }^{34}$ Thomas Charles-Edwards, 'Language and Society among the Insular Celts AD 400-1000', in The Celtic World, ed. Miranda J. Green (London, 1995), 703-36, at 711-15; Charles-Edwards, Wales and the Britons, 1-2.

${ }^{35}$ Ifor Williams (ed.) \& Rachel Bromwich (tr.), Armes Prydein: the Prophecy of Britain (Dublin, 1982), 2-3; Charles-Edwards, Wales and the Britons, 529. For the date of composition, see n. 57 below.
} 
seventh century. The borrowing may have occurred in the Northumbrian kingdom, in which case the Cumbras would undoubtedly have included the North Britons. ${ }^{36}$

Thus the term Cymry may reflect the self-designation of the North Britons, but it remains necessary to explain why neighbouring writers started to use Cumbrian terminology in a political sense in the tenth century. I would argue that the expansion of the kingdom rendered the geographical term Ystrat Clut inappropriate and necessitated the coining of a new term based on the kingdom's inhabitants. However, some historians doubt that the kingdom expanded at all. Charles-Phythian Adams has made the interesting proposal that enclaves of Brittonic-speakers survived south of the Solway during the period of Northumbrian domination, and that Brittonic identity re-emerged in a cultural and political sense in the early tenth century. ${ }^{37}$ Elsewhere I have restated the case that the kingdom expanded, but I have proposed a new model in which the expansion occurred in a piecemeal fashion over an extended period of time. ${ }^{38}$ It is therefore difficult to date Strathclyde's expansion, but one benchmark is King Athelstan's royal meeting by the River Eamont (Cumberland) in 927. Frank Stenton observed that treaties tended to be concluded on borders, and he proposed that the Eamont lay on the border between expanded Strathclyde and the area ruled from Scandinavian York. ${ }^{39}$ If so, we would expect contemporary writers to alter their nomenclature from 'Strathclyde' to 'Cumbria' around this time.

\footnotetext{
${ }^{36}$ The term was borrowed into English before the assimilation of - $m b$ - to - $m m$ - in Brittonic, which Kenneth Jackson dated to the sixth/seventh centuries: Language and History in Early Britain: a Chronological Survey of the Brittonic Languages, First to Twelfth Century A.D. (Edinburgh, 1953), pp. 509-11. For the suggestion that the borrowing occurred in Northumbria, see Woolf, 'Reporting Scotland', pp. 230-2. The term is, however, found in southern English place-names, for which see James, 'Cumbria Diaspora', 190-1.

${ }^{37}$ Phythian-Adams, Land of the Cumbrians. This model is presented as an alternative to Strathclyde's expansion in David Rollason, Northumbria, 500-1100: Creation and Destruction of a Kingdom (Cambridge, 2003), 24951; D. M. Hadley, The Vikings in England: Settlement, Society and Culture (Manchester, 2006), 62, 71.

${ }^{38}$ Fiona Edmonds, 'The Expansion of the Kingdom of Strathclyde', Early Medieval Europe (forthcoming).

${ }^{39}$ F. M. Stenton, 'Pre-Conquest Westmorland', in Royal Commission on Historical Monuments Westmorland (London, 1936); repr. in Doris Mary Stenton (ed.), Preparatory to Anglo-Saxon England (Oxford, 1970), 21423, at 218; Stenton, Anglo-Saxon England, $3^{\text {rd }}$ edn (Oxford, 1971), 332.
} 
The difficulty is that there are no certain contemporary references to 'Strathclyde' or 'Cumbria' between 920 and 945. The entry for 920 in the A manuscript of the Anglo-Saxon Chronicle reports that Edward the Elder built a burh at Bakewell (Derbyshire) and then various northern rulers chose him as father and lord, including Straecldwala cyning 7 ealle Stracledwealas. ${ }^{40}$ Some historians interpret this entry as a summary of the achievements of Edward's reign, but Clare Downham has convincingly argued that the entry can be accepted as a record of a meeting at Bakewell. ${ }^{41}$ The record is part of a continuation copied into the 'A' manuscript of the Chronicle during the second half of the tenth century, probably at Winchester. The chronicler's continued use of the term 'Strathclyde' is significant since he was a well-informed observer working at the heart of Edward the Elder's operations. ${ }^{42}$

The next relevant entry is found in the D version of the Chronicle and describes the royal meeting at Eamont in 927. The gathering was attended by Athelstan, Constantín of Alba, Hywel Dda, Ealdred of Bamburgh and a certain Owain, whom the chronicler associated with Gwent. ${ }^{43}$ In contrast William of Malmesbury, writing in 1125, designated Owain rex Cumbrorum ('king of the Cumbrians'). ${ }^{44}$ The participation of a northern Brittonic ruler is plausible since the royal meeting followed Athelstan's takeover of York in the face of a challenge from Guðrøðr, a member of the Scandinavian dynasty of Dublin. A set of northern annals records that Athelstan expelled Guðrøðr de regno Brittonum ('from the kingdom of the Britons'), which can be identified with Strathclyde/Cumbria given the text's northern

\footnotetext{
40 'the king of the Strathclyde Britons and all of the Strathclyde Britons'. ASC A 920 (ed. Bately), 69.

${ }^{41}$ Clare Downham, Viking Kings of Britain and Ireland: the Dynasty of Ívarr to A.D. 1014 (Edinburgh, 2007), 95-6, criticising A. Campbell, 'Two Notes on the Norse kingdoms in Northumbria', English Historical Review 57 (1942), 85-97, at 86 n. 6; Alfred P. Smyth, Scandinavian York and Dublin, 2 vols (Dublin, 1975-9), i, 110.

${ }^{42}$ Keynes, 'Manuscripts', 541-3.

43 ASC D [926] (ed. Cubbin, 41).

${ }^{44}$ R. A. B. Mynors et al. (ed. and tr.), William of Malmesbury, Gesta regum anglorum, 2 vols (Oxford, 1998), i, 214-15. Thomas Charles-Edwards (Wales and the Britons, 511-12) argues that both Owain of Gwent and Owain of Cumbria were present. For the latter, see Macquarrie, 'Kings of Strathclyde', 14-15.
} 
perspective. ${ }^{45}$ One of Athelstan's aims at Eamont may have been to re-establish diplomatic relations with the northern Brittonic ruler after the expulsion of Guðrøðr. Unfortunately it is unclear whether William of Malmesbury's term rex Cumbrorum ('king of the Cumbrians') derives from a contemporary source, or whether it represents the usage of the early twelfth century.

A similar difficulty surrounds references to the Cumbrian king Owain in twelfth-century texts from Durham. Symeon of Durham's Libellus de exordio, which was composed between 1104 and 1115, mentions Owain in connection with Athelstan's invasion of the kingdom of Alba (934). Fugato deinde Owino rege Cumbrorum et Constantino rege Scottorum, terrestri et nauali exercitu Scotiam sibi subiugando perdomuit. ${ }^{46}$ Symeon then notes that the kings of the Scots and the Cumbrians joined forces with Óláfr Guðrøðson to oppose Athelstan at the battle of Brunanburh (937). ${ }^{47}$ Another report of the battle is found in the complex twelfth-century compilation Historia regum, which also mentions the presence of a Cumbrian king. ${ }^{48}$ This information appears in a set of northern annals that contains tenth-century material, and so it is possible that the term rex Cumbrorum reflects contemporary usage. However, Symeon of Durham was probably involved with the compilation of Historia regum, and so the designation 'king of the Cumbrians' may simply represent the conventions of the early twelfth century. ${ }^{49}$

\footnotetext{
45 'Historia regum', in Thomas Arnold (ed.), Symeonis monachi opera Omnia, Rolls Ser., 2 vols (London, 18825), ii, 93; Smyth, Scandinavian York and Dublin, ii, 11-13; Charles-Edwards, Wales and the Britons, 521-2. The northern annals contain some tenth-century material. See below, n. 49.

46 'After this he put to flight Owain, king of the Cumbrians, and Constantín, king of the Scots; and he conquered Scotland with a land army and a naval force in order to make it subject to him'. David Rollason has established Symeon's authorship and the date-range in Rollason (ed. and tr.), Libellus de Exordio atque Procursu istius, hoc est Dunhelmensis, Ecclesie (Oxford, 2000), xx, xlii-xliv, 136-9.

${ }^{47}$ Ibid., 138-9.

48 'Historia regum' (ed. Arnold, ii, 93).

${ }^{49}$ For the northern annals see Peter Hunter Blair, 'Some Observations on the Historia regum attributed to Symeon of Durham', in N. K. Chadwick (ed.), Celt and Saxon: Studies in the Early British Border (Cambridge, 1963), 63-118, at 105-6; Clare Downham, 'The Chronology of the Last Scandinavian Kings of York, AD 937-
} 
It is unfortunate that there are no certain contemporary instances of the terms 'Strathclyde' or 'Cumbria' during the 920s and 930s since the kingdom is likely to have expanded substantially during that period. ${ }^{50}$ The first datable occurrence of Cumbrian terminology appears in various versions of the Anglo-Saxon Chronicle for 945: Her Eadmund cyning oferhergode eal Cumbra land 7 hit let eal to Malculme Scotta cyninge on paet gerad paet he waere his midwyrhta aegper ge on sae ge on lande. ${ }^{51}$ Alex Woolf has suggested that the term Cumbras reflects northern British usage, which was transmitted by Northumbrian writers. ${ }^{52}$ Some historians associate Cumbra land with the area south of Solway since the term survived there in the county, ward and deanery names 'Cumberland'. ${ }^{53}$ However, Cumbra is a genitive plural and so Cumbra land literally means 'land of the Cumbrians'. That this area included the Clyde Valley is indicated by the record of the 945 raid in the A-text of Annales Cambriae: Srat Clut uastata est a Saxonibus. ${ }^{54}$ This relatively late appearance of the term 'Strathclyde' can be explained by the chronicler's location; the A-text of Annales Cambriae was compiled at St Davids in south-western Wales in the mid-tenth century. ${ }^{55}$ The chronicler may have been unwilling to apply Cumbrian terminology to a specific northern British

\footnotetext{
954', Northern History 40 (2003), 25-51, at 36-7. For Symeon's possible involvement in Historia regum, see Libellus de exordio (ed. Rollason, p. xlix).

${ }^{50}$ Edmonds, 'The Expansion' (forthcoming).

51 'In this year King Edmund ravaged all Cumbra land and granted it to Máel Coluim, king of the Scots, on condition that he should be his ally both on sea and on land.' ASC A 945 (ed. Bately, 74), p. 74; ASC B [945] (ed. Taylor, 53); ASC C 945 (ed. O’Keeffe, 80); ASC D 945 (ed. Cubbin, 44); ASC E 945 (ed. Irvine, 55); Dorothy Whitelock (tr.), The Anglo-Saxon Chronicle: a Revised Translation (London, 1961), 72.

52 'Reporting Scotland', 230-1; cf. Woolf, From Pictland to Alba 789-1070 (Edinburgh, 2007), $153-4$.

${ }^{53}$ A. M. Armstrong et al., The Place-Names of Cumberland, English Place-Name Society 20-2 (Cambridge, 1950-2), i, 1; Phythian-Adams, Land of the Cumbrians, 111; A. A. M. Duncan, The Kingship of the Scots, 8421292: Succession and Independence (Edinburgh, 2002), 23-5.

54 'Strathclyde was ravaged by the English.' AC A 945 (ed. Dumville, 16-17); Armstrong et al., Place-Names, iii, xxvi; Hicks, 'Language, History', p. 30.

${ }^{55} A C$ (ed. Dumville, vii-x). Annales Cambriae is similar to the Latin chronicle that underpinned the Welsh texts known as Brut y Tywysogion and Brenhinedd y Saeson, which also contain the term (Y)strat Clut; see, for example, Brenhinoedd y Saeson 945 R \& S (ed. Dumville, 38-9).
} 
kingdom because the inhabitants of the various Welsh kingdoms were also Cymry. ${ }^{56}$

Similarly, the author of the Welsh text Armes Prydein, writing in the mid-tenth century, referred to the North Britons as Cludwys ('Clydesmen') when noting that they would be welcomed among the Cymry. ${ }^{57}$ Taken together, the Welsh and Anglo-Saxon records of the 945 raid indicate that the Clyde Valley was a core part of the area that was known as Cumbra land to the English.

Latin texts support the notion that, outside Wales, Cumbrian terminology superseded the kingdom name 'Strathclyde'. As mentioned above, the late-tenth-century English writer Æthelweard selected the term Cumbri to translate Strecledwalas ('Strathclyde Britons'). ${ }^{58}$ The term Cumbri also appears in the Life of St Cathroe, which was written shortly after the saint's death in $971 \times 976$. St Cathroe ended his life at Metz and the Life seems to have been written there, but it includes some well-informed material about northern Britain. ${ }^{59}$ Cathroe reportedly travelled from the kingdom of Alba to terra Cumbrorum ('the land of the Cumbrians'), where he met King Douenaldus (Dyfnwal). Dyfnwal left Cathroe with Eiríkr, a York king, at the boundary of the lands of the Cumbrians and the Northmen. ${ }^{60}$

Some further instances of Cumbrian terminology appear in accounts of the meeting between King Edgar and various other kings at Chester in 973. The southern English writer Ælfric

\footnotetext{
${ }^{56}$ Woolf, 'Reporting Scotland', 231. Welsh writers had started to restrict the term Cymry to Wales and the Welsh by the eleventh century; see Huw Pryce, 'British or Welsh? National Identity in Twelfth-century Wales', English Historical Review 116 (2001), 775-801, at 778, 796.

${ }^{57}$ See n. 35, above. The date of composition has provoked much debate, although many scholars place it in the years before or after the battle of Brunanburh (937). For recent discussion, see Charles-Edwards, Wales and the Britons, 520-32.

${ }^{58}$ See above, fnn. 15, 28.

${ }^{59}$ David N. Dumville, 'St Cathroe of Metz and the Hagiography of Exoticism', in John Carey et al. (eds.), Studies in Irish Hagiography: Saints and Scholars (Dublin, 2001), 172-88; repr. in his Celtic Essays, 20012007, 2 vols (Aberdeen, 2007), i, 159-82, at 168, 180.

${ }^{60}$ De S. Cadroe abbate, Acta Sanctorum Martii I (Antwerp, 1668), 476; tr. in Alan Orr Anderson, Early Sources of Scottish History, 2 vols (1922, repr. with corrections, Stamford, 1990), i, 441. Cathroe was led usque Loidam civitatem, which is often identified with Leeds, but that lies too far south. Other suggestions include Carlisle (Smyth, Scandinavian York and Dublin, ii, 181, 189, 295; rejected by Dumville, 'St Cathroe', 34 n. 35), Lowther (Clarkson, Men of the North, 180) and Leath ward (Alex Woolf, pers. comm.)
} 
produced a Life of St Swithin in the 990s, which states: and ealle ða cyningas pe on pysum iglande waron (Cumera and Scotta) comon to Eadgare - hwilon anes dages eahta cyningas - and hi ealle gebugon to Eadgares wissunge. ${ }^{61}$ Elfric may have intended the term Cumeras to include Welsh rulers since he does not mention them separately; that would, however, be a rare usage since the term Norðwealas was the usual term for the Welsh. ${ }^{62}$ The presence of a Cumbrian (i.e. northern Brittonic) king at the meeting is supported by the early twelfthcentury writers William of Malmesbury and John of Worcester. They mention the attendance of Malcolm rex Cumbrorum and they also refer to a certain Dufnal, who may be Máel Coluim's father Dyfnwal. ${ }^{63}$ Ann Williams has suggested that William and John provide a twelfth-century gloss on the events of 973 , given that Norman rulers aspired to a pan-British overlordship. She has also identified a likely source of their information: the witness list of a charter that was forged in the early twelfth century. ${ }^{64}$ Yet even if William and John's accounts reflect twelfth-century usage, Æthelweard's Chronicon and the Life of Cathroe demonstrate that Latin writers were applying Cumbrian terminology to the northern Brittonic kingdom by the late tenth century.

The rising popularity of Cumbrian terminology is further illustrated by its use in Scandinavian panegyrics attributable to late-tenth-century court poets. The earliest example is Pórsdrápa by Eilífr Goðrúnarson, a skald at the court of Hákon jarl, the most powerful ruler in Norway from 975-95. The poet employs terms for Insular and Scandinavian peoples when

\footnotetext{
61 'and all the kings of the Welsh (Cumbrians) and Scots who were in this island came to Edgar - once, on one and the same day, eight kings together - and they all submitted to Edgar's rule'. Michael Lapidge (ed. and tr.), Ælfric of Winchester, 'Life of St Swithun', in Lapidge, The Cult of St Swithun (Oxford, 2003), 606-7; for the date of the text, see ibid., 577.

${ }^{62}$ John Earle, rev. Charles Plummer (eds.), Two of the Saxon Chronicles Parallel, 2 vols (Oxford, 1892-9), ii, 418.

${ }^{63}$ R. R. Darlington and P. McGurk (eds.), The Chronicle of John of Worcester, 3 vols (Oxford, 1995-), ii, 4224; William of Malmesbury, Gesta regum (ed. Mynors et al.), i, 238-40. For the identification of Dufnal with Dyfnwal of Cumbria, see Stenton, Anglo-Saxon England, 369; David E. Thornton, 'Edgar and the Eight Kings, AD 973: textus et dramatis personae', Early Medieval Europe 10 (2001), 49-79, at 66-7.

${ }^{64}$ Ann Williams, 'An Outing on the Dee: King Edgar at Chester, AD 973', Mediaeval Scandinavia 14 (2004), 229-44; P. H. Sawyer, Anglo-Saxon Charters: an Annotated List and Bibliography (London, 1968), no. 808.
} 
alluding to the giants against whom the god Pórr fights. These include hellis hringbalkar Kumrar ('Cumbrians of the cave's circular wall'). ${ }^{65}$ Another early example appears in Óláfsdrápa by Hallfreðr vandræðaskáld Óttarsson, a poem composed in honour of Óláfr Tryggvason (d. 1000). Here kumbrskar pjóðir ('Cumbrian peoples') are mentioned in the same stanza as brezkrar jarðar byggvendr ('the inhabitants of British land'). ${ }^{66}$ Thus

Cumbrians are distinguished from other Britons, presumably because Cumbrian terminology was restricted to the inhabitants of a northern British polity. The Norse term kumbrar also appears in place-names within the kingdom, notably the Cumbrae islands in the Firth of Clyde (Kummreyjar, 1260s; capellam de Cumbraye $1328 \times 1337){ }^{67}$

Thus Cumbrian terminology is attested during the mid- to late-tenth century in English, Norse and Latin texts. As we have seen, Welsh texts continued to feature the term Ystrat Clut but this is because Welsh writers were unwilling to restrict the term Cymry to one, northern kingdom. Irish texts offer the only other exceptions to the general prevalence of Cumbrian terminology by the second half of the tenth century. The so-called Fragmentary Annals refer to an otherwise unknown attack on Strathclyde: Tainig rí Lochlannach iar $t$-tain, \& ra airg Sraith Cluaidhe, \& ra airg an tír. Acht ní ro cumaing namaid do Sraith Chluaidhe. ${ }^{68}$ The attack purportedly occurred in the early tenth century, when the term 'Strathclyde' would still

\footnotetext{
${ }^{65}$ Pórsdrápa 13, ed. Edith Marold, 'Skaldic Poetry of the Scandinavian Middle Ages', http://abdn.ac.uk/skaldic/db.php?table=poems\&id=170 [consulted on 29/11/2012]; cf. Snorri Sturluson, Edda Skáldskaparmál 2: Glossary and Index of Names, ed. Anthony Faulkes (London, 1998; repr. 2007), 318. I am grateful to Dr Jonathan Grove for drawing my attention to the references in skaldic verse.

${ }^{66}$ Óláfsdrápa 5, ed. Diana Whaley, in Poetry from the Kings' Sagas 1: From Mythical Times to c.1035 (Brepols, forthcoming); cf. 'Skaldic Poetry of the Scandinavian Middle Ages', http://abdn.ac.uk/skaldic/db.php?table=poems\&id=258 [consulted on 29/11/2012]; John Hines, Old-Norse Sources for Gaelic History, Quiggin Lecture 5 (Cambridge, 2002), 13, 27. Russell Poole has suggested that the terms brezkr and Bretar might be applied to inhabitants of Wales or Strathclyde: 'Skaldic Verse and AngloSaxon History: some Aspects of the Period 1009-1016', Speculum 62 (1987), 265-98, at 292-3. I prefer the interpretation in Judith Jesch, Ships and Men in the Late Viking Age: the Vocabulary of Runic Inscriptions and Skaldic Verse (Woodbridge, 2001), 77.

${ }^{67}$ I am grateful to Gilbert Márkus for supplying these references.

68 'The king of the Norwegians came after that and sacked Strathclyde and plundered the land. But the enemy was ineffectual against Strathclyde': FAI (ed. and tr. Radner), 182-3.
} 
have been in general use. However, some portions of the Fragmentary Annals derive from a mid-eleventh-century chronicle and this particular entry bears an eleventh-century imprint in its use of the term Lochlannaich for 'Norwegians' ${ }^{69}$ The term Strath Cluaide may have persisted amongst Irish writers in the eleventh century because they were familiar with the prímscél ('chief tale') Argain Sratha Cluada ('the plundering of Strathclyde'). We do not which plundering the tale described, or whether it affected the whole kingdom or merely Clydesdale. ${ }^{70}$ Otherwise, Irish annalists tended to refer to kings of Strathclyde/Cumbria as rí Bretan ('king of the Britons') or rí Bretan tuaiscirt ('king of the northern Britons'). This reflects the terminology used for other northern British rulers, such as Eadwulf of Bamburgh rí Saxan tuaiscirt. ${ }^{71}$

To sum up, Cumbrian terminology had generally superseded the kingdom name 'Strathclyde' by the mid-tenth century. The northern Brittonic polity was no longer designated by a geographical expression; rather, Cumbra land and terra Cumbrorum mean 'land of the Cumbrians'. Cumbrian terminology tended to appear in the designations of the rulers of the northern Brittonic polity and so the shift in nomenclature reflects a political development. In my view, this development is likely to be Strathclyde's expansion, which diminished the utility of a name based on one river valley. Cumbrian terminology embraced the areas both north and south of Solway, unlike the term 'Strathclyde'.

\section{The demise of the Cumbrian kingdom}

\footnotetext{
${ }^{69}$ Clare Downham, 'The Good, the Bad and the Ugly: Portrayals of Vikings in "The Fragmentary Annals of Ireland"', in E. Kooper (ed.), The Medieval Chronicle III (Amsterdam, 2004), 27-39.

${ }^{70}$ The tale is no longer extant but is listed in the twelfth-century Book of Leinster: R. I. Best et al. (ed.), The Book of Leinster, formerly Lebar na Núachongbála, 6 vols (Dublin, 1954-1983), iv, 836; cf. Edmund Hogan, Onomasticon Goedelicum (Dublin, 1910), 616; W. J. Watson, A History of the Celtic Place-Names of Scotland (Edinburgh, 1926), 192. The plundering may have been the attack on Dumbarton by Óláfr and Ívarr in 870 (in which case the term 'Strathclyde' may have been retrospectively applied to the kingdom) or, as Dauvit Broun suggests, a plundering of Britons in 1030 (see n. 89, below).

${ }^{71}$ AU 913.1, 975.2, 997.5 (ed. Mac Airt and Mac Niocaill, 360-1, 412-13, 426-7).
} 
For the remainder of the article, I will consider the ways in which Cumbrian terminology evolved during the eleventh and twelfth centuries. I will argue that the terms were employed in different ways once the Cumbrian polity had ceased to exist, and that the range of meanings appropriate to the later eleventh and twelfth century should not be retrospectively applied to the kingdom's heyday in the tenth century. The particular problem of the eleventh century is the obscurity of the kingdom's demise: it is often unclear whether Cumbrian terminology applied to the former polity or to its component parts.

The English king Æthelred opened the eleventh century by leading an army into Cumerlande and attacking the Isle of Man. The manoeuvre followed a build-up of Scandinavian activity in the Isles and the Irish Sea region during the 980s; the Cumbrian kings seem to have benefited from an alliance with the Islesmen at this time. ${ }^{72}$ The Cumbrian kingdom was still fully operational, the last known king being alive in 1018. Therefore this reference to Cumerland seems to relate the polity as a whole, including the areas north of Solway. Indeed, long-term interaction between Cumbrians and Islesmen may have influenced some of the material culture at Govan in Clydesdale. ${ }^{73}$

By the early eleventh century, the Cumbrian kingdom was coming under threat from the expansionist earldom of Bamburgh. ${ }^{74}$ The Northumbrian earls may have started to bring portions of Cumbrian territory under their rule, which would explain why provisions are

\footnotetext{
72 ASC C 1000 (ed. O’Keeffe, 88); ASC D 1000 (ed. Cubbin, 50); ASC E (ed. Irvine, 63); Downham, Viking Kings, 170, 196-7.

${ }^{73}$ S. T. Driscoll, 'Church Archaeology in Glasgow and the Kingdom of Strathclyde', Innes Review 49 (1998), 95-114, at 112-13; Downham, Viking Kings, 167-70. For the kingdom's maritime interests, see also Ross, Kings of Alba, 136, 144, 174.

${ }^{74}$ William E. Kapelle, The Norman Conquest of the North: the Region and its Transformation, 1000-1135 (London, 1979), 37-44, 249; Woolf, From Pictland, 260-3; Fiona Edmonds, 'Personal Names and the Cult of Patrick in Eleventh-Century Strathclyde and Northumbria' in Steve Boardman et al. (ed.), Saints' Cults in the Celtic World, Studies in Celtic History 25 (Woodbridge, 2009), 42-65, at 51-5; Clarkson, Men of the North, 190.
} 
made for Britons in the early eleventh-century text Norðleoda laga ${ }^{75}$ The dismemberment of the Cumbrian kingdom would also account for a change terminology: Owain Foel is designated rex Clutinensium ('king of the Clydesmen') in a report of the battle of Carham (1018). This information appears in a section of Historia regum that is based on John of Worcester's Chronicle, but the relevant entry was added by a northern writer; it may therefore reflect a Northumbrian perspective in which the Cumbrian polity was being reduced to the Clyde Valley. ${ }^{76}$ Against this argument, much of the kingdom possessed continued coherence, re-emerging as the diocese of Glasgow in the twelfth century. ${ }^{77}$ Nevertheless, it is possible that portions of the kingdom were broken up and then reunified during the turbulence of the eleventh century, as a recent examination of the Lennox postulates. ${ }^{78}$

The Northumbrian earl Siward loosely dominated much of the Cumbrian kingdom by the mid-eleventh century. ${ }^{79}$ Siward defeated Mac Bethad in 1054 and then installed Máel Coluim regis Cumbrorum filius ('son of the king of the Cumbrians') as king. ${ }^{80}$ Scholars used to identify this Máel Coluim with the future Máel Coluim III, king of Scots; in this scenario the latter's father, Donnchad, would have been 'king of the Cumbrians' ${ }^{81}$ This interpretation is in line with Fordun's perception of Cumbria as an appanage for future heirs of the Scottish kings but, as we have seen, Fordun's framework is no longer generally accepted. Moreover, A. A. M. Duncan has convincingly argued that the Máel Coluim in question belonged to the

\footnotetext{
${ }^{75}$ F. Liebermann (ed.), Die Gesetze der Angelsachsen (3 vols, Halle, 1903-16), i, 460; Patrick Wormald, The Making of English Law: King Alfred to the Twelfth Century. Vol. 1, Legislation and its Limits (Oxford, 1999), 391-4, 457.

76 'Historia regum' (ed. Arnold, ii, 156); Hunter Blair, 'Some Observations', 107-111.

${ }^{77}$ See e.g. Broun, 'Welsh Identity', 139 n. 117.

${ }^{78}$ Ross, Kings of Alba, 141-3.

${ }^{79}$ It should be noted that Siward ruled his earldom under the English kings; see Clarkson, Men of the North, 191-3.

${ }^{80}$ John of Worcester, Chronicle (ed. Darlington and McGurk), ii, 574-5; William of Malmesbury, Gesta regum (ed. and trans. Mynors et al.), i, 348-9.

${ }^{81}$ E.g. Kirby, 'Britons and Angles', 88.
} 
dynasty of Strathclyde/Cumbria and was probably the son of Owain Foel. ${ }^{82}$ It seems that Siward was acting as the senior partner in an alliance with the last-known member of the Cumbrian dynasty in 1054 .

Siward's influence in formerly Cumbrian territory is also attested in the text known as 'Gospatric's writ', which dates from the mid- to late-eleventh century. ${ }^{83}$ The text opens with Gospatric greeting his retainers on eallun pam landann peo weoron Combres ('in all the lands that were Cumbrian'). Earl Siward and Gospatric are said to have granted the peace to Thorfynn mac Thore, an important person in the locality, and so the text supports the idea that Northumbrian authorities wielded power in parts of the former Cumbrian kingdom. There has been some debate about the identity of the Gospatric who was responsible for the text: the two candidates are Gospatric son of Uhtred (d. 1064), ${ }^{84}$ or his nephew Gospatric son of Maldred, who held the Northumbrian earldom in 1067-8 and 1070-2. ${ }^{85}$ Charles PhythianAdams has observed that the writ only survives in an inaccurate thirteenth-century copy, and so it is impossible to determine whether Gospatric was operating under Siward's aegis or as Siward's successor. ${ }^{86}$ Whichever Gospatric issued the text, it is clear that some lands south of Solway had recently been Cumbrian, but were no longer considered to be so. The places mentioned are Allerdale (which occupied a smaller area than the later barony of that name), Cardew and Cumdivock; the latter are located near the boundary of Allerdale. The

\footnotetext{
${ }^{82}$ Duncan, Kingship, 37-41.

${ }^{83}$ For the most recent edition and translation, see David Woodman, Charters of Northern Houses, Anglo-Saxon Charters 16 (Oxford, 2012), 370-1.

${ }^{84}$ H. W. C. Davis, 'Cumberland before the Norman Conquest', English Historical Review 20 (1905), 61-5; Armstrong et al., Place-Names, iii, xxvii, xxx; F. E. Harmer, Anglo-Saxon Writs (Manchester, 1952), 420, 526; Kapelle, Norman Conquest, pp. 44, 249-50.

85 James Wilson, 'An English Letter of Gospatric', SHR 1 (1904), 62-9, at 63; Anderson, Early Sources, ii, 369; Kirby, 'Strathclyde', 93; Phythian-Adams, Land of the Cumbrians, 174-81.

${ }^{86}$ Phythian-Adams, Land of the Cumbrians, 175.
} 
designation 'Cumbrian' seems to be used in a political rather than a linguistic sense here since Brittonic place-names were still being coined in the area in the late eleventh century. ${ }^{87}$

The fate of the area north of the Solway is less certain, although there are some indications that Northumbrian interests extended into the north of the former Cumbrian kingdom. ${ }^{88}$ Dauvit Broun has postulated a carve-up of the kingdom between Northumbrians and GallGoídil, pointing to a ravaging of Britons by English and Dubliners in $1030 .{ }^{89}$ The Gall-Goídil certainly came to dominate some of the lands around the Firth of Clyde, leading areas such as Strathgryfe to be designated 'Galloway' rather than 'Cumbria'. ${ }^{90}$ Meanwhile, the inland core of the kingdom seems to have remained intact under Northumbrian domination. This area became vulnerable to the Scottish king Máel Coluim III in the aftermath of the Norman Conquest, which provoked rebellion in the North of England. Gospatric son of Maldred was one of the ringleaders in 1068-9, but he bought back the Northumbrian earldom from William the Conqueror in 1070. By this time Cumbreland was under the control of Máel Coluim III non jure possessa sed violenter subjugata ('not possessed by right but subdued by force'). This information appears in one of the northern entries in the Historia regum, which states that Gospatric attacked Cumbreland in reprisal for one of Máel Coluim's raids. ${ }^{91}$ It is tempting to associate this area with the later county, but the term may simply be a rendering of Cumbra land ('land of the Cumbrians'). ${ }^{92}$

\footnotetext{
${ }^{87}$ Kenneth Jackson, 'Angles and Britons in Northumbria and Cumbria', in H. Lewis (ed.), Angles and Britons: O’Donnell Lectures (Cardiff, 1963), 60-84, at 82; Hicks, 'Language, History', 94-5; James, 'Dating Brittonic Place-Names', 76-7, 88.

${ }^{88}$ Edmonds, 'Personal Names', 53.

${ }^{89}$ AT [1030] (ed. Stokes, 370); Broun, 'Welsh Identity', 136-7. As Broun notes, the Dubliners had an interest in south-west Scotland at this time, and sometimes operated alongside Gall-Goídil. The suggestion also receives support in Ross, Kings of Alba, 139.

${ }^{90}$ Thomas Clancy, 'The Gall-Ghàidheil and Galloway', Journal of Scottish Name Studies 2 (2008), 19-50.

91 'Historia regum' (ed. Arnold, ii, 191); trans. in Alan O. Anderson, Scottish Annals from English Chroniclers A.D. 500-1286 (London, 1908; repr. Stamford, 1991), 92. This section derives mostly from John of Worcester's Chronicle, but the entry in question was added by a northern writer; see above n. 76 .

92 The form Cumbreland also appears in the twelfth-century Durham tract De primo Saxonum adventu (ed. Arnold, ii, 372) in a section describing the reign of Athelstan.
} 
The meagre evidence for the eleventh century allows for several interpretations of the Cumbrian kingdom's demise. I am persuaded by the view that the kingdom lost its northerly maritime territories to Gall-Goídil, while the Northumbrians extended loose rule over the inland core. This was the Cumbreland that the Scottish king Máel Coluim conquered during the aftermath of the Norman conquest of England. The area south of Solway may have remained under Scottish control until William Rufus captured Carlisle in 1092, creating the first securely attested division between Cumbrian lands north and south of the Solway. ${ }^{93}$

\section{The twelfth-century legacy}

The decline of the Cumbrian kingdom enabled Cumbrian terminology to be used in new ways during the twelfth century. There is a considerable amount of material available for that period but I will not attempt a comprehensive survey here. Rather, I aim to demonstrate that the terms could be restricted to smaller areas, or to more specific concepts, than had been the case in the tenth century.

One notable development was the restriction of the term Cumberland to the area south of Solway. An early instance appears in one of David I's earliest acts as king of Scots, which grants Annandale to Robert de Brus to hold cum omnibus illis consuetudinibus quas Randulfus Meschin' unquam habuit in Cardiull' 7 in terra sua de Cumberland'. Richard Sharpe has argued that Ranulf governed Carlisle and the surrounding area on behalf of the

\footnotetext{
93 ASC E 1092 (ed. Irvine, 103); John of Worcester, Chronicle (ed. McGurk, iii, 62-3); Judith Green, 'AngloScottish Relations, 1066-1174', in Michael Jones and Malcolm Vale (eds.), England and her Neighbours, 1066-1453 (London, 1989), 56-7; Henry Summerson, Medieval Carlisle: The City and the Borders from the Late Eleventh to the Mid-Sixteenth Century, 2 vols (Kendal, 1993), i, 1, 11, 14-18, 47-9; Aird, 'Northern England', 27-8; J. G. Scott, 'The Partition of a Kingdom: Strathclyde 1092-1153', Transactions of the Dumfriesshire and Galloway Natural History and Antiquarian Society, 72 (1997), 11-40, at 15-18.
} 
king, and that he gave up the role in 1121 or $1122 .{ }^{94}$ The wording allows for the possibility that Ranulf's terra was only one part of Cumberland (his land of Cumberland). Nevertheless, the term Cumberland seems to be used in a very restricted way in this charter since it excludes Carlisle. ${ }^{95}$

The development of the county of Cumberland facilitated the restriction of the term Cumberland to the area south of Solway. Six acts of Henry I address the men of Cumberland, who had started to meet in a way similar to a shire by 1130 , but the area still lacked its own sheriff. ${ }^{96}$ To illustrate this point, Richard Sharpe has drawn attention to Henry’s writ-charter granting certain lands to Hildred of Carlisle and his son (October $1129 \times$ September 1130), which addresses Odard (probably of Bamburgh) as sheriff. ${ }^{97}$ The writ-charter is addressed omnibus fidelibus suis francis et anglis de Cumberland' ('to all his sworn men French and English of Cumberland') and Hildred's lands are granted under the same terms as other free men holding of the king in Cumberland. Thus although the county of Cumberland had not yet fully emerged, public institutions and royal officers were being put in place in the area. By the time David I took control of the area at the end of 1135, there was a sheriff serving in Carlisle. ${ }^{98}$ Soon afterwards, David granted to the monks of Wetheral (Cumberland) a pension of one mark of silver yearly from the revenue of his mill at Scotby. The act begins $D$ (auid) regis Scot(torum) comit<i> iustic(ie) baronibus uic(ecomiti) ministris omnibus probis

\footnotetext{
94 'with all the customs which Ranulf Meschin ever had in Carlisle and in his land of Cumberland'. The Charters of David I, ed. G. W. S. Barrow (Woodbridge, 1999), 61-2 ; cf. Dauvit Broun, The Charters of Gaelic Scotland and Ireland in the Early and Central Middle Ages, Quiggin Lecture 2 (Cambridge, 2002), 1-3; Richard Sharpe, Norman Rule in Cumbria 1092-1136, CWAAS Tract Series 21 (Kendal, 2006), 50-2.

${ }^{95}$ Sharpe, Norman Rule, 48-9.

${ }^{96}$ Ibid., 5-33.

${ }^{97}$ Ibid., 12-22.

${ }^{98}$ Ibid., 64-7. For David's activities in Carlisle, see Green, 'Anglo-Scottish Relations', 66-7; Summerson, Carlisle, i, 38-44; Keith J. Stringer, 'State-Building in Twelfth-Century Britain: David I, King of Scots, and Northern England', in Appleby and Dalton (eds.), Government, Religion, 40-62; Barrow, 'King David I', 118.
} 
hominibus suis totius Cumberland Francis et Anglis et Cumbrensibus. ${ }^{99}$ Sharpe has argued that formulae such as Francis et Anglis et Cumbrensibus tended to have a linguistic resonance but, as he notes, it is doubtful whether Brittonic-speakers still made up a substantial part of the population in the Carlisle area by the 1130s. The term Cumbrenses may therefore apply to the people native to the new county of Cumberland in this context. ${ }^{100}$ On the other hand, a now-lost charter quoted by the antiquary John Denton also featured Cumbrenses in its address clause. This charter related to Gilsland, where there are numerous late Brittonic place-names, and to a man bearing the Brittonic personal name Wescop (GwasEscop, 'devotee of the bishop'). ${ }^{101}$

From this point on, the term Cumberland tended to apply to the county in address clauses, but the term could also be applied in a more restricted fashion to the deanery and ward of Cumberland. The rural deaneries and wards are first recorded in the thirteenth century, but they may preserve earlier territorial divisions. ${ }^{102}$ Cumberland ward and deanery are contiguous rather than overlapping: the ward reached from the River Wampool to the Solway and inland part-way along the River Eden, while the deanery stretched from there to the Pennine edge. Phythian-Adams makes the interesting observation that royal lands were clustered in this area, and he postulates that this was the core of the kingdoms of Rheged and Cumbria. ${ }^{103}$ Nevertheless, there is no need to identify Cumberland ward, deanery or county with the Cumbra land ('land of the Cumbrians') of the Anglo-Saxon Chronicle. As I have

\footnotetext{
99 'David king of Scots to the earl and justice and his barons and sheriffs and officials and all his worthy men of Cumberland, French and English and Cumbrian'. For the reading, see Richard Sharpe, 'Peoples and Languages in Eleventh- and Twelfth-Century Britain and Ireland: Reading the Charter Evidence' (Paradox of Medieval Scotland Project, 2011), 94-5 (accessed on-line 13/01/2013: poms.cch.kcl.ac.uk/redist/pdf/SharpeFinal.pdf ). Cf. Barrow, Charters of David I, 89-90. This act is dated $1136 \times 1141$, perhaps 1138 or 1139 .

${ }^{100}$ Sharpe, 'Peoples and Languages', 95; for the interpretation of Cumberland see also Barrow, 'King David I', 119.

${ }^{101}$ John Denton's History of Cumberland, ed. Angus J. L. Winchester, Surtees Soc. 213 (2010), 82; I owe this reference to Professor Winchester. For the name, see Edmonds, 'Personal Names', 49-50.

${ }^{102}$ Angus J. L. Winchester, Landscape and Society in Medieval Cumbria (Edinburgh, 1987), 14-16; cf. Armstrong et al., Place-Names, iii, xiv-xv; Barrow, 'Pattern of Lordship', 127.

${ }^{103}$ Phythian-Adams, Land of the Cumbrians, 111.
} 
noted, that territory included the Clyde Valley, and so twelfth-century senses of the term Cumberland cannot be retrospectively applied to the tenth-century polity.

Moving on to the term Cumbria, this appears most prolifically in a group of twelfth-century texts associated with the church of Glasgow. The earliest is David's Inquest, which the future David I carried out in order to explore the lands pertaining to the church of Glasgow. David's title is Cumbrensis regionis princeps ('prince of the Cumbrian region') and he is said to have investigated the lands pertaining to Glasgow in singulis Cumbrie provinciis que sub dominio et potestate eius erant ('the individual parts of Cumbria which were then under his sway and control'). The writer admitted non enim toti Cumbrensi regioni dominabatur ('he (David) did not in fact rule all of the Cumbrian region'); this is presumably a reference to the area south of Solway, which became part of the Anglo-Norman realm in $1092 .{ }^{104}$ The lands mentioned in the Inquest have not all been conclusively identified, but they include clusters around Glasgow, in Upper Clydesdale, Annandale, Tweeddale and Teviotdale. ${ }^{105}$ Thus Cumbria not only extended to the south of the Clyde Valley, but also over the hills on its south-eastern side. It is unclear whether Teviotdale was part of the Cumbrian kingdom in its heyday, and several ecclesiastical authorities disputed control of the territory in the twelfth century. Dauvit Broun suggests that it was a late acquisition, transferred to Owain the Bald after he helped defeat the Northumbrians at the battle of Carham (1018). ${ }^{106}$

\footnotetext{
${ }^{104}$ Green, 'Anglo-Scottish Relations', 60-1; Ross, Kings of Alba, 207-8. This identification is more likely than the areas around the Firth of Clyde (as suggested by Scott, 'Partition of a Kingdom', 30-2; Clarkson, Men of the North, p. 194) because those areas lay in Gall-Goídil territory, as demonstrated by Clancy, 'The GallGhàidheil'.

${ }^{105}$ Cosmo Innes (ed.), Registrum Episcopatus Glasguensis: Munimenta Ecclesie Metropolitane Glasguensis, a Sede Restaurata Seculo Ineunte XII, ad Reformatam religionem, 2 vols, Bannatyne and Maitland Clubs (Edinburgh and Glasgow, 1843) [Glasgow Reg.], i, 4-5; J. T. T. Brown, The Inquest of David: Facsimile and Text (Glasgow, 1901); Charters of David I, ed. Barrow, 60-1. For the Clydesdale lands, see Grant, 'Lordship and Society', 107-8. John Durkan has identified two names in the Inquest with places in Cowal and the Lennox: 'Cowal part of Strathclyde in the Early Twelfth Century', Innes Review 54 (2003), 230-3.

${ }^{106}$ Broun, 'Welsh Identity', 139, n. 117. For Teviotdale disputes, see also Barrow, Kingdom of the Scots, $205-6$.
} 
Glasgow continued to promote its association with the Cumbrian polity in the era of Herbert, bishop 1147-64. A surviving fragment of a Life of St Kentigern commissioned by Herbert asserts that the saint's miracles were still occurring per Cambriam. ${ }^{107}$ St Kentigern was the patron saint of the church of Glasgow and so this sentence associates Glasgow's sphere of influence with the Cumbrian region. The choice of the form Cambria rather than Cumbria may reflect the appearance of the term Cambria in Geoffrey of Monmouth's popular Historia regum Britanniae. The difficulty is that Geoffrey distinguished Cambria (Wales) from Albania (Scotland); an alternative possibility is that the Glasgow writer was influenced by Welsh ecclesiastical terminology. ${ }^{108}$ Whatever its origin, the term Cambria proved useful since it enabled Glasgow to distinguish its diocese from the area south of Solway, which belonged to the diocese of Carlisle by this time. ${ }^{109}$ Thus there was a subtle shift in the application of Cumbrian terminology during the mid-twelfth century in order to reflect Glasgow's contemporary sphere of influence.

The use of the term Cambria also reflects the appropriation of Cumbrian terminology for new purposes during the mid- to late-twelfth century. Dauvit Broun has argued persuasively that Glasgow diocese associated itself with the 'Cambrian' kingdom in order to avoid incorporation into the proposed archbishopric of St Andrews or the archbishoprics of York or Canterbury. ${ }^{110}$ The connection between the kingdom and the diocese is further emphasised in Jocelin of Furness's Life of Kentigern, which was written at the behest of Jocelin, bishop of Glasgow 1174-99. Kentigern is elected bishop by the king and clergy of the regnum

\footnotetext{
${ }^{107}$ Lives of S. Ninian and S. Kentigern (ed. and tr. Forbes, 124, 244).

${ }^{108}$ Michael D. Reeve (ed.) and Neil Wright (tr.), The History of the Kings of Britain: an Edition and Translation of De gestis Britonum (Woodbridge, 2007), 30-1. The writers at St Davids were particularly prone to use the term Cambria: Pryce, 'British or Welsh?', 797-8.

${ }^{109}$ Helen Birkett, The Saints' Lives of Jocelin of Furness: Hagiography, Patronage and Ecclesiastical Politics (Woodbridge, 2010), 177-81.

${ }^{110}$ Broun, 'Welsh Identity', 140- 71; Broun, Scottish Independence, 124-57.
} 
Cambrinum and the diocese is said to be coterminous with that kingdom. ${ }^{111}$ Jocelin of Furness portrays the kingdom as reaching from sea to sea along the course of the Antonine Wall which Scociam ab Anglia disterminando dividit ('by division separates Scotia from Anglia'). ${ }^{112}$ This image furthers Jocelin's argument that the diocese of Glasgow lay between Scotland and England, and so ought to be independent from English or Scottish archbishoprics. ${ }^{113}$ Nevertheless, there are other indications that the Cumbrian polity once stretched to the east of the Clyde Valley, as noted above. ${ }^{114}$ As to the southern extent of the kingdom, Jocelin's Life depicts Kentigern temporarily placing his see at Hoddom (Annandale), which David's Inquest listed as one of the possessions of the church of Glasgow. Jocelin also portrays Kentigern operating to the south of the Solway, but the episode may reflect an expansion of Kentigern's cult during the reign of David I rather than a memory of the original extent of the Cumbrian kingdom. ${ }^{115}$

Overall, it seems that the terms Cumberland and Cumbria/Cambria began to be used in different ways during the twelfth century, but there was still scope for ambiguity and overlap. David I addressed his officers of the whole of Cumberland when he granted to Glasgow the eighth part of his pleas per totam Cumbriam, which in this context must relate to the diocese of Glasgow. ${ }^{116}$ We have already seen that the term Cumbrenses might be restricted to the new county of Cumberland, but this term also encompassed men from north of the Solway in

\footnotetext{
${ }^{111}$ Lives of S. Ninian and S. Kentigern (ed. and tr. Forbes), 54-5, 181-3.

${ }^{112}$ Ibid., 55, 183.

${ }^{113}$ Broun, 'Welsh Identity', 141-2; Broun, Scottish Independence, 125-6. Cumbria is said to lie inter Angliam et Scotiam in the late-twelfth-century prologue to David's Inquest: Glasgow Reg., I, 3.

${ }^{114}$ See above, p. 00. Kapelle (Norman Conquest, 130, 266-7) associates Jocelin's image with Glasgow's claims on Teviotdale.

${ }^{115}$ Lives of S. Ninian and S. Kentigern (ed. and tr. Forbes, 74, 92-5, 200, 217-19); John Reuben Davies, 'Bishop Kentigern among the Britons', in Boardman et al. (eds.), Saints' Cults, 66-90, at 75-83, 88-90.

${ }^{116}$ Barrow, Charters of David I, 81-2. Barrow notes: "Cumbria" and "Cumberland" of this document were surely equivalent to the "Cumbria" of the well-known Inquest of David' ('King David I', 119).
} 
some accounts of the activities of David I's army in $1138 .{ }^{117}$ Conversely, the term Cumbria was not only applied to the diocese of Glasgow, but also to a component part of the diocese of Carlisle. ${ }^{118}$ Thus, the longstanding application of Cumbrian terminology to areas north and south of Solway still had an impact on twelfth-century writers. Indeed, David appreciated Cumbria's former extent when he conducted his Inquest, and this notion may have been relevant to his expansion south of the Solway. Nevertheless, contemporary developments meant that the terms Cumberland and Cumbria were used in new and specific ways as the twelfth century wore on.

To conclude, the lack of texts from the northern Brittonic kingdom means that the native term for the polity remains obscure, but the rulers and inhabitants of the kingdom may have thought of themselves as Cymry. This term was applied to Brittonic-speakers elsewhere, notably in Wales, but in the North it displaced 'Strathclyde' as the name for a kingdom. This raises an interesting problem because parts of the Cumbrian kingdom were multi-lingual and multi-cultural; the late-twelfth-century prologue to David's Inquest notes that the polity encompassed diverse tribus diversarum nationum ex diversis partibus ('different peoples of different nations from different regions'). ${ }^{119}$ Some of the inhabitants spoke languages other than Brittonic; were they embraced by the literal meaning of the term Cymry ('inhabitants of the same region')? The Cumbrians may have identified themselves as the followers of the

\footnotetext{
${ }^{117}$ For example, Richard of Hexham distinguished Cumbri from the men of Carlisle and surrounding area: De gestis Regis Stephani, in Richard Howlett (ed.), Chronicles of the Reigns of Stephen, Henry II and Richard I, Rolls Ser., 4 vols (London, 1884-9), iii, 159. For other references to Cumbri/Cumbrenses, see ibid., iii, 152; Ailred of Rievaulx, Relatio de Standardo, in ibid., iii, 190. Cf. Summerson, Carlisle, I, 39-40; Barrow, 'King David I', 121.

${ }_{118}^{118}$ Phythian-Adams, 'From Peoples', 63 n.8.

${ }^{119}$ Glasgow Reg., I, 3-4; Grant, 'Lordship and Society', 112; Charles-Edwards, Wales and the Britons, 95. Thomas Clancy has explored this problem in an unpublished paper: 'From the Siege of Dumbarton to the Men of Stobo: the Rise and Fall of the Kingdom of Cumbria' (2003). For multiculturalism, see also Crawford, Govan Hogbacks; Courtney Helen Buchanan, 'Scandinavians in Strathclyde: Multiculturalism, Material Culture and Manufactured Identities in the Viking Age', in Historic Bute: Land and People, ed. Anna Ritchie (Edinburgh, 2012), 17-32.
} 
Cumbrian dynasty since this was a period when leaders across Britain and Ireland sought to appeal to a variety of ethnic groups. ${ }^{120}$

It is appropriate to focus on the political context because Cumbrian terminology usually accompanied references to the kings or their territory. In my view, Cumbrian terminology began to be used in a political sense when the kingdom of Strathclyde expanded to the south and east of its Clyde Valley heartland, rendering Ystrat Clut obsolete as a political term. ${ }^{121} \mathrm{~A}$ later political development, namely the decline of the kingdom, also affected the use of Cumbrian terminology. By the twelfth century, the terms Cumberland and Cumbria/Cambria were being used in new and restricted ways in response to changing political and ecclesiastical circumstances. Twelfth-century usage should not, however, be applied retrospectively to the tenth-century kingdom, which stretched from Clydesdale to the area south of Solway.

\footnotetext{
${ }^{120}$ Máire Herbert, 'Rí Éirenn, Rí Alban, Kingship and Identity in the Ninth and Tenth Centuries', in Kings, Clerics and Chronicles in Scotland, 500-1297, ed. Simon Taylor (Dublin, 2000), 62-72, at 64, 69.

${ }^{121}$ Edmonds, 'The Expansion' (forthcoming).
} 